\title{
Laser-assisted Joining of Steel and Cellulose Fiber-reinforced PMMA
}

\author{
Tamás Csiszér $^{1}$, Tamás Temesi ${ }^{2}$, Lajos Borbás $^{3}$, László Molnár $^{3}$ \\ ${ }^{1}$ Óbuda University, Rejtő Sándor Faculty of Light Industry and Environmental \\ Protection Engineering, Doberdó út 6, H-1034 Budapest, Hungary \\ csiszer.tamas@rkk.uni-obuda.hu \\ ${ }^{2}$ Budapest University of Technology and Economics, Faculty of Mechanical \\ Engineering, Department of Polymer Engineering, Müegyetem rakpart 3, H-1111 \\ Budapest, Hungary, temesit@pt.bme.hu \\ ${ }^{3}$ EDUTUS University, Engineering Institute, Stúdium tér 1, H-2800 Tatabánya, \\ Hungary, borbas.lajos@edutus.hu; molnar.laszlo@edutus.hu
}

\begin{abstract}
Laser Assisted Metal-Polymer Joining Technologies (LAMP) are widely used to create hybrid structures for different purposes. If the laser beam is transported to the connected surfaces from the polymer's side, the polymer has to be adequately transparent on the wavelength of the applied radiation to avoid degradation and to ensure effective and efficient adhesion. The transparency can be affected by the components and the structure of the polymer. The long-term goal of our research is to identify, assess and quantify the connection between the type and the amount of reinforcing fibers and the quality of metalpolymer joining. In this paper, we introduce the key findings of the first experiments aimed at joining steel and poly(methyl-methacrylate) reinforced with different amounts of cellulose fibers. We identified the optimal values of some laser technology parameters (e.g. power, velocity) that affect the strength and the visual appearance of joining.
\end{abstract}

Keywords: laser welding; hybrid joints; steel; PMMA

\section{Introduction}

An important aim in the vehicle industry, including companies from the automobile, railway and aerospace industries, is to reduce both the manufacturing and the operating costs of their vehicles. A possible way to achieve this is to use lighter materials, for example, polymers and polymer composites and combine them with metal parts into integrated structures using fast and reliable joining techniques. These integrated structures must have comparable mechanical properties to single-material components that are currently used in the vehicles. With lighter, less dense materials, the weight of the vehicle can be reduced, fuel 
can be saved, and emissions can be lowered. Furthermore, the processing and forming of polymers and polymer composites can be achieved with less energy input, compared to metal and glass products $[2,16,23,32,35]$.

The techniques and methods, with which metal and polymer structures can be joined have been a hot topic in recent years. Particular attention is paid to technologies that make it possible to form joints between metal and polymer materials without the use of an intermediate element (for example adhesive or standard fasteners), within the framework of mass production (with short cycle time, in an automated manner). Welding techniques that are widely used to join plastics (for example friction, ultrasonic, and laser welding) can also be used to manufacture joints between materials with dissimilar chemical structures [1, 3-5, $10,12,14,20-22,24,28,33,34]$.

Laser welding stands out from these techniques, as it is an easily automatable, non-contact joining method, with which two or more structures can be joined simultaneously, and the realized joint is solid, watertight, and stress-free. Furthermore, heat is only generated near the seam, thus the thermal degradation of the welded structures can be avoided. Laser beam welding can only be used if one of the materials can absorb the energy of the laser radiation [5, 30, 33, 34].

When a laser beam is used to create a joint between metals and polymers the technique is usually called Laser-Assisted Metal-Polymer, or LAMP joining technology. In addition to joining process parameters, the surface preparation of the metal part and the degree of compatibility between metal and polymer also have a significant effect on the joint strength $[6,10,13,20,21,28,30]$, since plastics and metals differ significantly in both physical and chemical structures. For this reason, the joint is usually based on adhesion. In this case, secondary chemical bonds are formed between the molten polymer and the surface oxide layer of the metal during the joining process [5]. The load-bearing capacity of the joint is further influenced significantly by the structure and conformation of the polymer chains [11], by the type and amount of monomer residues and additives in the polymer, and by the surface structure of the metal [6-9]. However, when optimal joining process parameters are chosen, the adhesion between metal and polymer can be even stronger than the cohesion of the polymer material [27].

Metals and polymers can be joined using laser radiation in two ways: the first is the so-called transmission joining method, while the second is the so-called direct laser joining process (Figure 1). The essence of the transmission joining (indirect fusion) process is that the polymer component is transparent to laser radiation, i.e. it transmits most of the energy (without bending or scattering) of the laser beam. When a metal part is placed under such a transparent polymer structure, the laser radiation is absorbed in the metal part and is converted into heat. The generated heat reaches the polymer part through heat conduction in the metal and heat transfer on the interface between the metal and polymer parts. If enough heat is 
produced, the polymer melts and flows into the surface structures on the surface of the metal part $[5,33,34]$.

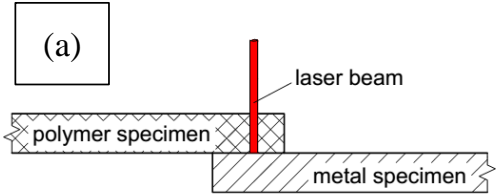

Transmission laser joining

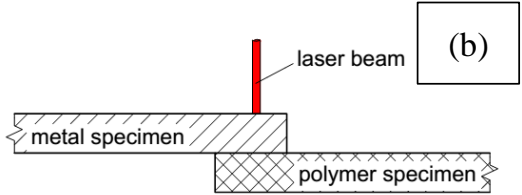

Direct laser joining

Figure 1

Schematic of the transmission laser joining (a) and the direct laser joining (b) joining techniques

The so-called direct laser joining process is mainly used to join metal and polymer materials if the polymer is not transparent enough on the wavelength of the laser radiation. This may be caused by the use of fillers, additives or reinforcing materials, or due to the microstructure of the polymer), or if it is prone to thermal degradation. During direct laser joining, the laser radiation directly heats the metal part and does not pass through the polymer material $[5,33,34]$.

Polymethyl-methacrylate (PMMA) is a polymer material widely used in medicine (in dentistry, in implants, and other medical devices) as bone cement and in the vehicle industry, mainly as headlight and dashboard equipment covers [5, 26, 29]. In the latter cases, PMMA covers must be joined to other elements or even to the structural elements of the vehicle itself. Until recently, this was done using adhesives most of the time, as the joint must be watertight and solid. In recent years, however, laser welding gained traction as a joining technique for PMMAmetal structures [10, 13, 20, 21, 26, 28].

There are relatively few publications specifically dealing with the joining of PMMA and steel plates with laser joining. Bauernhuber et al. manufactured overlapped and pin-to-plate joints between structural steel (1.0038) and PMMA using the same welding equipment. In the case of overlapped joints, they investigated the effect of surface preparation (rolled and sandblasted surfaces), power and duration of pulses emitted by the pulsed-mode laser welding machine, different joining speeds, and focal spot diameters on the properties of the formed joints. They confirmed that surface preparation significantly increases the strength of the formed joints. Increasing the focal spot diameter and the joining speed, however, reduces the strength of the joints because in these cases, less laser energy is absorbed and less heat is formed in the metal specimen. Thus, the polymer also melts less thoroughly. With the applied parameters, no correlation could be proven between the laser power and the strength of the joints. In pin-toplate joints, the effect of irradiation time, as well as the surface roughness of the steel pin was investigated. They found that increasing the irradiation time increased joint strength. There was a similar effect when the surface roughness of the pins was increased, which was explained by the formation of undercuts and better absorption of laser radiation energy [7-9]. Markovits and Berczeli [25] 
investigated the effect of different laser beam power, feed rate and clamping pressure values and the effect of sandblasting on the strength of structural steel (1.0038) - PMMA joints manufactured using a $\mathrm{CO}_{2}$ laser and the direct laser joining method. They found that increasing the clamping pressure and using sandblasted steel specimens both increased the shear strength of the joints, and also influenced the size and amount of bubbles that formed near the seam in the PMMA material. They explained the increase in shear strength with better laser absorption and better adhesion between steel and PMMA when sandblasted specimens were used. In their publication, Hussein et al. used the one-factor-at-atime method and response surface methodology to search for the optimal joining process parameters when they joined PMMA and stainless steel (1.4301) using both the transmission laser joining and the direct laser joining techniques. They found that by increasing the thermal input, the strength of the joint also increased. However, there was an optimal thermal input value, over which the polymer material started to degrade, and the joint strength decreased with both joining techniques. They also found that joint strength was the highest when the top hattype beam shape was used [18]. In a later article, Hussein et al. built a finite element model based on their results and findings to be able to predict and calculate the thermal distribution and the thermal history of seams manufactured between steel-PMMA samples with both laser joining techniques [19]. Huang et al. used the same 1.4301-type stainless steel and PMMA to manufacture joints, and they examined the effect of the joining process control parameters and the flow rate of argon shielding gas on the strength of the joints. They found trends consistent with the observations published by Bauernhuber et al., and Hussein et al. [17].

In recent years, reducing the amount of plastic waste became a hot topic and generated action plans both on a governmental level and in the industry. For example, Directive 2000/53/EC of the European Council describes the amount of polymer-based structures to be reused and/or recycled when a road vehicle is scrapped. Beyond recycling, special attention is given to prolong the life expectancy of polymer-based parts by modifying their mechanical properties. One such possible method is to use fiber reinforcement. Several publications showed results on the joining of fiber-reinforced thermoplastic composites and metal sheets with laser joining, in which glass or carbon fibers were mixed to varying degrees into polyamide, a material frequently used in the automotive industry [15, 31]. However, no research so far has been published on the applicability and use of fibrous reinforcements from renewable resources, specifically cellulose fibers.

The subject of our research is the joining of plastic reinforced with a bio-based reinforcing agent (PMMA filled with cellulose fibers) and structural steel (1.0038) with the transmission joining and direct laser joining techniques and the mechanical and optical examination of the joints. In this publication, we present the optical properties and weldability of PMMA material reinforced to different degrees with cellulose fibers and the possibilities and parameters of creating 
hybrid joints between steel and cellulose fiber-reinforced PMMA sheets. We also present our experimental design, the methods used in the creation and testing of the joints, the optimal values of the technological parameters, and other results obtained during the mechanical and optical testing of the joints.

\section{Materials and Methods}

\subsection{Raw Materials}

The most important parameters of the raw materials used to manufacture the test specimens for our investigations are summarized below.

The steel specimens used to create the joints were cut from a $0.8 \mathrm{~mm}$ thick structural steel (S235JR/1.0038) sheet using a high-power laser cutting device. The specimens were $30 \mathrm{~mm}$ long and $10 \mathrm{~mm}$ wide.

We used two PMMA raw materials from two different manufacturers: the first type of PMMA we used is sold as Sitramac HW55, a PMMA-polystyrene copolymer made by Sitraplas $\mathrm{GmbH}$, Germany. This material had a distinct grey tone even when no reinforcing agent was added to it. The second type of PMMA is called Altuglas VS-UVT, which is manufactured by the Arkema group. This PMMA is highly transparent in the visible and near-infrared spectrum.

For the reinforced composite specimens, we added 1 to 10 weight percent (whole numbers only) of Arbocel B600 cellulose fibers, a product of J. Rettenmeier \& Söhne GmbH, to the PMMA raw materials.

\subsection{Test Specimen Manufacturing}

We manufactured the polymer test specimens for our experiments with compounding and injection molding. For the unreinforced PMMA specimens, we dried the material at $80^{\circ} \mathrm{C}$ for 8 hours (as recommended by the manufacturers), then used a twin-screw extruder (LTE 26-44, Labtech Engineering Company Ltd., Thailand) with an ascending temperature profile to manufacture an endless filament. This was then pelletized for injection molding on an Arburg Allrounder 270S 400-170-type injection molding machine. The compounding procedure was done so that the thermal history of the unreinforced material is as close to the reinforced materials as possible.

For the cellulose fiber-reinforced PMMA specimens, we followed the same steps: besides the PMMA raw material, we also dried the cellulose fibers at $80^{\circ} \mathrm{C}$ for 8 hours. Then, we made dry mixtures using neat PMMA pellets and different amounts of cellulose fibers, which we compounded using the same parameters on 
the same LTE 26-44 twin-screw extruder. Filaments containing the cellulose fibers were again pelletized and injection molded using the same Arburg IM machine.

For the optical tests, standard, dog bone-shaped specimens were manufactured from both raw materials, both with and without reinforcement. For the joining tests, $2 \mathrm{~mm}$ thick, flat, rectangular specimens of the size of $80 \times 80 \mathrm{~mm}$ were manufactured from the compounded, reinforced, and unreinforced pellets. $10 \mathrm{~mm}$ wide specimens were cut from them using a VersaLaser VLS 2.30-type $\mathrm{CO}_{2}$ laser for the joining processes.

\subsection{Specimen Testing}

The wavelength-dependent transparency of the unreinforced and cellulose fiberreinforced specimens was determined by using a Perkin-Elmer Lambda 1050 spectrophotometer. It can be stated that even with the incorporation of $1 \mathrm{wt} \%$ of cellulose fibers, the transparency of the specimens significantly decreases (from about $80 \%$ to about $30 \%$ in the case of the Sitramac material, and from about $90 \%$ to about $20 \%$ in the case of the Altuglas material) (Figure 2). This causes significant problems during transmission joining: less transparent specimens absorb more of the energy of the laser radiation, which can cause the degradation of the polymer material as well as prevent the formation of the joint itself. With this in mind, we performed the transmission joining experiments by setting lower laser power values, which also allowed us to determine the minimum laser power value required to create a durable, solid joint. More than $1 \mathrm{wt} \%$ of reinforcement also prevented joint formation in the case of transmission laser joining. As our aim was to manufacture and compare joints using the two different joining techniques (transmission joining and direct laser joining), we only used specimens containing $0 \mathrm{wt} \%$ and $1 \mathrm{wt} \%$ cellulose fiber. 


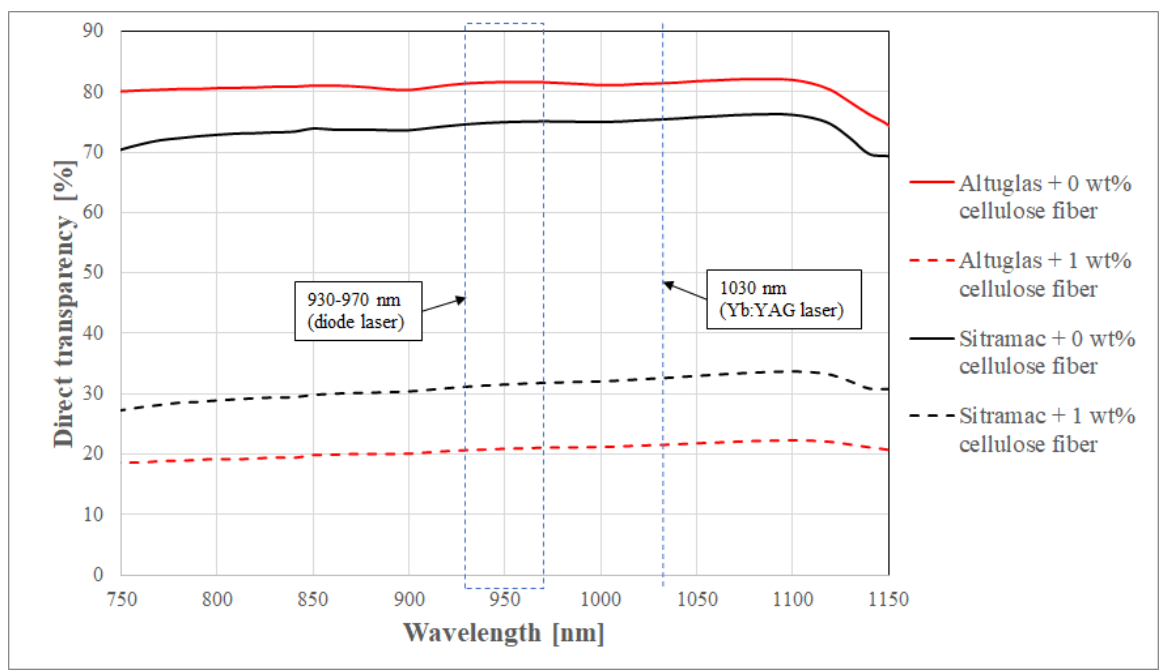

Figure 2

Transparency of unreinforced and reinforced (with $1 \mathrm{wt} \%$ cellulose fiber) PMMA specimens

\subsection{Manufacturing and Testing of Steel-Polymer Joints}

Two types of laser joining methods (transmission laser joining and direct laser joining, Figure 1) and two types of laser welding machines were used to create the overlapped joints. Before joining, the surfaces of both steel and polymer specimens were wiped with a cloth soaked in methanol, to degrease their surfaces. In our experiments, we did not change the surface structure of the metal specimens.

During transmission laser joining, the polymer specimen was placed on top of the steel specimen. The transmission joining was performed on a Trumpf TruDiode 151 diode laser, with a laser wavelength range of $930-970 \mathrm{~nm}$. The laser power was set to $110,130 \& 150 \mathrm{~W}$ (Figure 3).
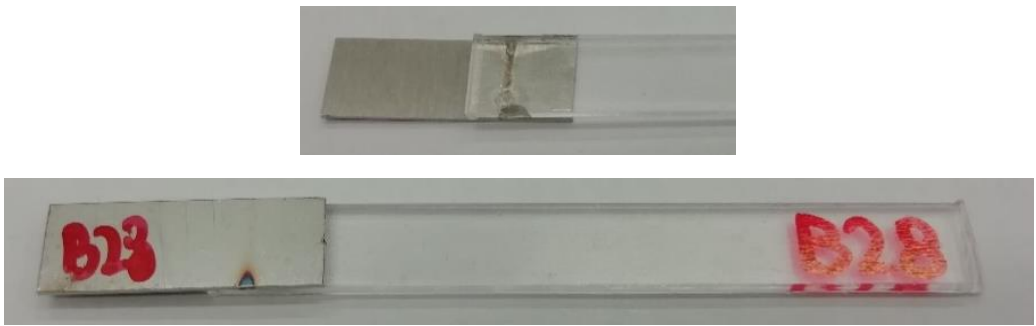

Figure 3

Overlapped specimens manufactured with the transmission laser joining technique using unreinforced

Altuglas PMMA and steel 
During direct laser joining, the steel specimens were placed on top of the polymer specimens. These joints were made using a Trumpf TruDisk $4001 \mathrm{Yb}$ : YAG solidstate laser (with a wavelength of $1030 \mathrm{~nm}$ ) housed in a Trump TruLaser Cell 7020 CNC cell. The laser power was set to $210,230 \& 250 \mathrm{~W}$ (Figure 4).
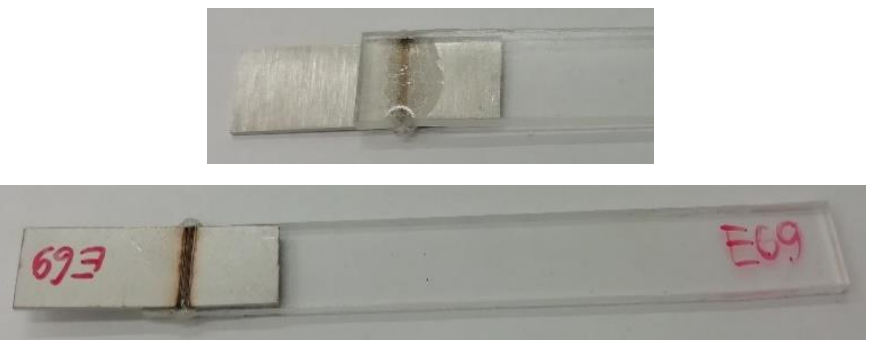

Figure 4

Overlapped specimens manufactured with the direct laser joining techniques using unreinforced Altuglas PMMA and steel

The joints were formed by linear joining with both techniques: the laser beam irradiated the specimens three times along the same line. The joining speed for both methods was set to $1 \mathrm{~m} \cdot \mathrm{min}^{-1}$ so that the joints were as comparable as possible. The strength and durability of the joints were evaluated using a Zwick Z005 universal material testing machine by compressive (shear) tests (Figure 5a). As the steel-PMMA joints behave in a rather brittle manner based on our preliminary experiments, the test speed was set to $1 \mathrm{~mm} \cdot \mathrm{min}^{-1}$. The joints were loaded to failure. The joint surface of the polymer specimens was investigated, and the size of the joined surfaces was quantified using a Keyence VHX-5000 optical microscope (an example is shown in Figure 5b).
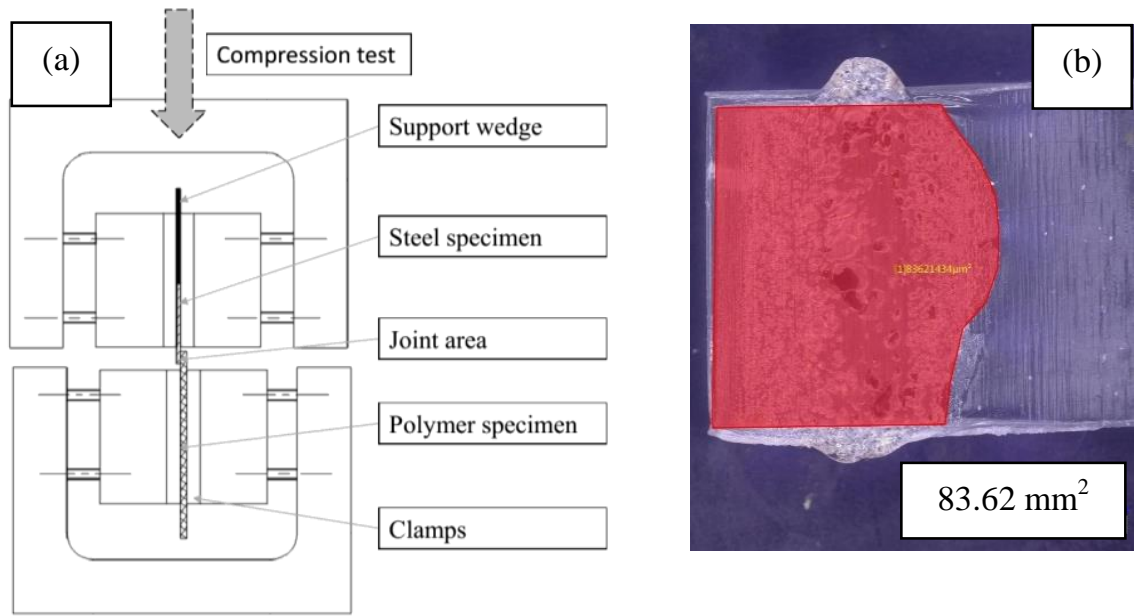

Figure 5

Schematic of the compression test performed on the welded specimens (a), and evaluating the joint surface on the specimen shown in Figure 4 using the Keyence VHX-5000 optical microscope (b) 


\section{Experimental Design}

Based on our preliminary experiments, the mechanical properties of the joints are influenced by the type of polymer, the fiber content, and the laser power in addition to the applied joining method (transmission or direct laser joining). We experimentally determined the technological window and the ideal values (based on subjective examination of the strength and aesthetics of the created joints) for these process control parameters. These values are as follows

- Equipment: Trumpf TruDiode 151 with a maximum power output of 150 W or Trumpf TruDisk $4001 \mathrm{Yb}$ :YAG disc laser with a maximum power output of $4 \mathrm{~kW}$;

- Laser beam power: $30 \mathrm{~W}-250 \mathrm{~W}$;

- Laser beam velocity: $1 \mathrm{~m} / \mathrm{min}$;

- Type of irradiation: direct (from metal part) and transmission (from polymer part);

- Type of joining: projection joining;

- Number of cycles: 3 .

Based on this technological window, three further experiments were designed (Table 1).

1. The purpose of the first experiment (denoted by C1) was to apply as low power as possible to create joints with transmission laser joining to minimize the degradation of the polymer. We created a full-factorial $\left(2^{\mathrm{p}}\right)$ design with the following parameters:

- PMMA: Sitramac and Altuglas;

- Reinforcement: $0 \mathrm{wt} \%$ and $1 \mathrm{wt} \%$ cellulose;

- Laser beam power: $30 \mathrm{~W}, 40 \mathrm{~W}$ and $50 \mathrm{~W}$;

- Equipment: Trumpf TruDiode 151 with a maximum power output of 150 W;

- Laser beam velocity: $1 \mathrm{~m} / \mathrm{s}$;

- Type of joining: projection joining;

- Number of cycles: 3 .

- Type of irradiation: transmission joining (from polymer part);

- Number of specimens: 10 pcs for each combination of factor settings.

2. The purpose of the second experiment (denoted by C3) was to apply as high power as possible to maximize the strength of the joints with transmission laser joining with acceptable degradation of the polymer. We created another full-factorial $\left(2^{\mathrm{p}}\right)$ design with the following parameters: 
- PMMA: Sitramac and Altuglas;

- Reinforcement: $0 \mathrm{wt} \%$ and $1 \mathrm{wt} \%$ cellulose;

- Laser beam power: $110 \mathrm{~W}, 130 \mathrm{~W}$, and $150 \mathrm{~W}$;

- Equipment: Trumpf TruDiode 151 with a maximum power output of 150 W;

- Laser beam velocity: $1 \mathrm{~m} / \mathrm{s}$;

- Type of joining: projection joining;

- Number of cycles: 3 .

- Type of irradiation: transmission joining (from polymer part);

- Number of specimens: 10 pcs for each combination of factor settings.

3. The purpose of the last experiment (denoted by $\mathrm{C} 2$ ) was to test whether the polymer part affects the strength of joints when specimens are irradiated by the laser beam from the metal part. We created a third fullfactorial $\left(2^{\mathrm{p}}\right)$ design with the following parameters:

- PMMA: Sitramac and Altuglas;

- Reinforcement: $0 \mathrm{wt} \%$ and $1 \mathrm{wt} \%$ cellulose;

- Laser beam power: $210 \mathrm{~W}, 230 \mathrm{~W}$, and $250 \mathrm{~W}$;

- Equipment: Trumpf TruDisk $4001 \mathrm{Yb}: Y A G$ disc laser with a maximum power output of $4 \mathrm{~kW}$;

- Laser beam velocity: $1 \mathrm{~m} / \mathrm{s}$;

- Type of joining: projection joining;

- Number of cycles: 3 .

- Type of irradiation: direct joining (from metal part);

- Number of specimens: 10 pcs for each combination of factor settings.

Table 1

Experiment designs for optimizations of laser beam joining parameters for different purposes

\begin{tabular}{|c|c|c|c|}
\hline $\begin{array}{c}2^{\mathrm{p}} \\
\text { Experiments }\end{array}$ & $\mathrm{C} 1$ & C3 & $\mathrm{C} 2$ \\
\hline Purpose & $\begin{array}{l}\text { To apply as low } \\
\text { power as possible } \\
\text { to create joints with } \\
\text { transmission laser } \\
\text { joining to minimize } \\
\text { the degradation of } \\
\underline{\text { the polymer. }}\end{array}$ & $\begin{array}{l}\text { To apply as high } \\
\text { power as possible } \\
\text { to maximize the } \\
\frac{\text { strength of the }}{\text { joints with }} \\
\text { transmission laser } \\
\text { joining with } \\
\text { acceptable } \\
\text { degradation of the } \\
\text { polymer. }\end{array}$ & $\begin{array}{c}\text { To test whether the } \\
\text { polymer part } \\
\text { affects the strength } \\
\text { of joints when } \\
\text { specimens are } \\
\text { irradiated by the } \\
\text { laser beam from the } \\
\text { metal part. }\end{array}$ \\
\hline
\end{tabular}




\begin{tabular}{|c|c|c|c|}
\hline \multirow[b]{2}{*}{ PMMA } & \multirow{2}{*}{\multicolumn{3}{|c|}{ Sitramac and Altuglas }} \\
\hline & & & \\
\hline Reinforcement & \multicolumn{3}{|c|}{$0 \mathrm{wt} \%$ and $1 \mathrm{wt} \%$ cellulose } \\
\hline $\begin{array}{l}\text { Laser beam } \\
\text { power }\end{array}$ & $\begin{array}{c}30 \mathrm{~W}, 40 \mathrm{~W} \text { and } 50 \\
\mathrm{~W}\end{array}$ & $\begin{array}{c}110 \mathrm{~W}, 130 \mathrm{~W} \text { and } \\
150 \mathrm{~W}\end{array}$ & $\begin{array}{l}210 \mathrm{~W}, 230 \mathrm{~W} \\
\text { and } 250 \mathrm{~W}\end{array}$ \\
\hline Equipment & \multicolumn{2}{|c|}{$\begin{array}{l}\text { Trumpf TruDiode } 151 \text { with a maximum } \\
\text { power output of } 150 \mathrm{~W}\end{array}$} & $\begin{array}{c}\text { Trumpf TruDisk } \\
4001 \mathrm{Yb}: \text { YAG disc } \\
\text { laser with a } \\
\text { maximum power } \\
\text { output of } 4 \mathrm{~kW}\end{array}$ \\
\hline Velocity & \multicolumn{3}{|c|}{$1 \mathrm{~m} / \mathrm{min}$} \\
\hline $\begin{array}{l}\text { Type of } \\
\text { joining }\end{array}$ & \multicolumn{3}{|c|}{ projection joining } \\
\hline No. of cycles & \multicolumn{3}{|c|}{3} \\
\hline $\begin{array}{l}\text { Type of } \\
\text { irradiation }\end{array}$ & \multicolumn{2}{|c|}{ Transmission joining (from polymer part) } & $\begin{array}{c}\text { Direct joining } \\
\text { (from metal part) }\end{array}$ \\
\hline $\begin{array}{c}\text { No. of } \\
\text { specimens }\end{array}$ & \multicolumn{3}{|c|}{$10 \mathrm{pcs}$ for each combination of factor settings } \\
\hline
\end{tabular}

\section{Experimental Results}

The degradation of the polymer was qualified by the flame intensity in $\mathrm{C} 2$. The strength of joining was tested by compression shear tests in a Zwick Z005 universal testing machine. The effective joining area was measured and calculated for each tested specimen on a Keyence VHX-5000 optical microscope. The levels of significance of factors' effects were analysed by Minitab and MS Excel.

The shear strength of the joints was calculated by dividing the maximum force and the area of joining (1).

$$
\tau=\frac{F_{\max }}{A}[M P a](1)
$$

It was proven on $95 \%$ confidence level that the power of the laser beam had a significant effect on the strength of joints, but only in experiments $\mathrm{C} 2$ and $\mathrm{C} 3$. In experiment $\mathrm{C} 2$ the matrix material also had a significant effect on the strength of joints as well (Table 2). The intensity of flame (i.e. the degradation of polymer) was affected significantly only by the power of laser beam. The amount of fiber and combinations of factors have no significant effect on any of the dependent variables. 
Table 2

Significant factors for the strength of joining

\begin{tabular}{|l|c|c|c|}
\hline Factors & Experiment C1 & Experiment C2 & Experiment C3 \\
\hline Laser Beam Power & No & Yes & Yes \\
\hline Matrix Polymer & Yes (?) & Yes & Yes (?) \\
\hline Fiber Amount & No & No & No \\
\hline
\end{tabular}

The values of average compression strength of joints are demonstrated in Figs. 68. In Experiment C1 (Figure 6) shear strength could be calculated only in the case of Sitramac PMMA. The reason for this is that in the case of the Altuglas PMMA, the adhesion between metal and polymer was not strong enough to create measurable joints. Results suggest that the difference between matrix materials determines shear strength, but this theory could not be proven statistically due to the missing shear force values. It seems that the optimum value of laser beam power is $40 \mathrm{~W}(T=5.81 \mathrm{MPa})$, and cellulose fibers weaken the connection in the case of $30 \mathrm{~W}$ and $40 \mathrm{~W}$, but strengthen it in the case of $50 \mathrm{~W}$ power. Since the effects of these factors are not significant, the logical connections between the difference in shear strength, laser beam power, and amount of reinforcement are not proven.

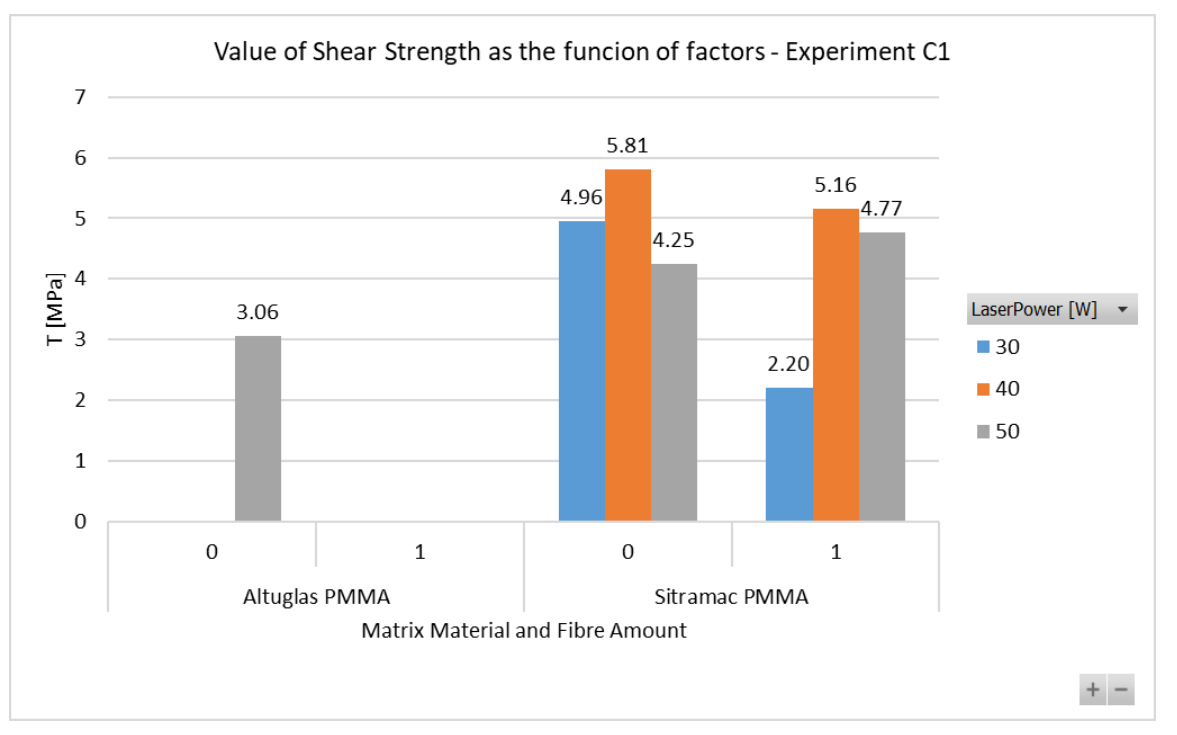

Figure 6

Average values of Shear Strength for different factor combinations - Experiment C1

The same logical connection can be seen in Experiment C3 (Figure 7): the higher the laser beam power is, the stronger the adhesion is. In the case of Sitramac PMMA, shear strength seems to be greater than that of Altuglas PMMA, but it is not proven by ANOVA. The amount of reinforcing fibers used does not influence 
adhesion significantly. So, the optimal choice is $150 \mathrm{~W}$ and Sitramac PMMA matrix, resulting in $\mathrm{T}=2.34 \mathrm{MPa}$.

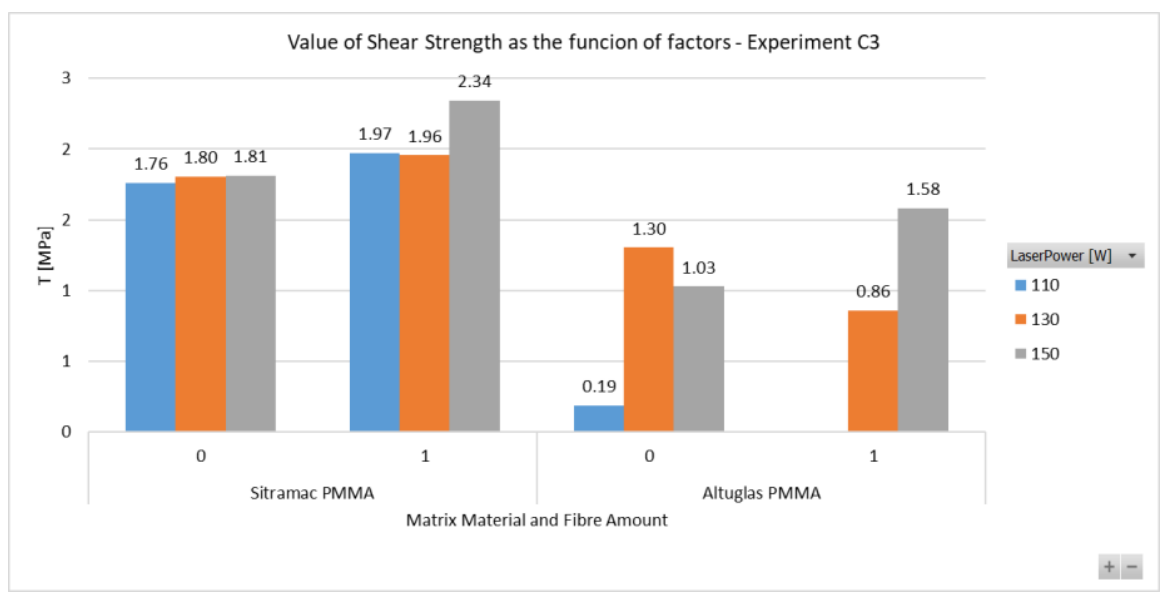

Figure 7

Average values of Shear Strength for different factor combinations - Experiment C3

In Experiment C2 (Figure 8) the statistically proven optimal choice is $250 \mathrm{~W}$ and Sitramac PMMA ( $T=5.61 \mathrm{MPa})$. Results suggest that fibers weaken adhesion in the case of $230 \mathrm{~W}$ and $250 \mathrm{~W}$, but strengthen in case of $210 \mathrm{~W}$.

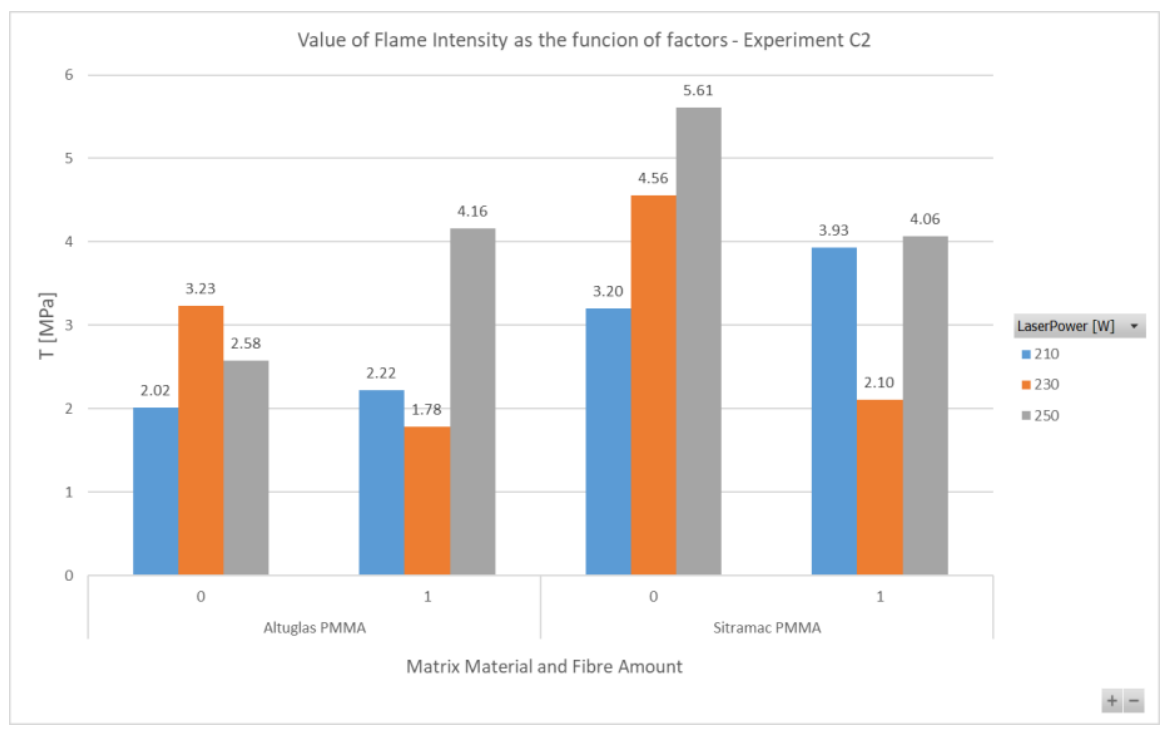

Figure 8

Average values of Shear Strength for different factor combinations - Experiment C2 


\section{Conclusions}

It is proven that PMMA - steel joints can be created by NIR laser beam both with direct and transmission irradiation methods. Maximum values of shear strength of joining are 5.61 MPa (250 W, Sitramac PMMA) and 5.81 MPa (40 W, Sitramac PMMA). Adding $1 \mathrm{wt} \%$ of reinforcing fiber to the polymer does not influence the adhesion significantly. Due to relatively small strength, these kinds of PMMA steel hybrid joints can be used primarily as non-load-bearing structures and as an additional joining method to traditional and stronger joining techniques.

\section{Acknowledgment}

This work was supported by the Grant No. EFOP-3.6.1-16-2016-00009, "Basic research project in the field of laser beam technologies and energetics".

\section{References}

[1] I. T. Abdullah, S. K. Hussein: Shear strength and temperature distribution model of friction spot lap joint of high density polyethylene with aluminum alloy 7075. International Journal of Structural Integrity, 10(4), pp. 469-483, 2019

[2] A. Albert, W. Zorn, M. Layer, W.-G. Drossel, D. Landgrebe, L. Kroll, W. Nendel: Smart process combination for aluminum/plastic hybrid components. Technologies for Lightweight Structures, 1(2), pp. 44-53, 2017

[3] A. Al-Obaidi, C. Majewski: Ultrasonic welding of polymer-metal hybrid structures. In: Transactions on Intelligent Welding Manufacturing (Eds.: S. Chen, et al.). https://doi.org/10.1007/978-981-13-3651-5_2

[4] S. T. Amancio-Filho, C. Bueno, J. F. dos Santos, N. Huber, E. Hage Jr.: On the feasibility of friction spot joining in magnesium/fiber reinforced polymer composite hybrid structures. Materials Science and Engineering A, 528, pp. 3841-3848, 2011

[5] S. T. Amancio-Filho, L. Blaga: Joining of polymer-metal hybrid structures - principles and applications. John Wiley \& Sons, Inc., Hoboken, NJ, 2018

[6] S. Arai, Y. Kawahito, S. Katayama: Effect of surface modification on laser direct joining of cyclic olefin polymer and stainless steel. Materials and Design, 59, pp. 448-453, 2014

[7] A. Bauernhuber, T. Markovits: Laser assisted joining of metal pins and thin plastic sheets. Physics Procedia, 39, pp. 108-116, 2012

[8] A. Bauernhuber, T. Markovits: Investigating thermal interactions in the case of laser assisted joining of PMMA plastic and steel. Physics Procedia, 56 , pp. 811-817, 2014 
[9] A. Bauernhuber, T. Markovits, J. Takács: Investigating the pulse mode laser joining of overlapped plastic and metal sheets. Physics Procedia, 83, pp. 1094-1101, 2016

[10] R. Borrisutthekul, A. Saengsai, P. Mitsomwang: Dissimilar materials laser welding between stainless steel 304 and thermoplastics. Key Engineering Materials, 719, pp. 142-148, 2016

[11] J. Cheon, S. J. Na: Relation of joint strength and polymer molecular structure in laser assisted metal and polymer joining. Science and Technology of Welding and Joining, 19(8), pp. 631-637, 2014

[12] H. A. Derazkola, R. K. Fard, F. Khodabakhshi: Effects of processing parameters on the characteristics of dissimilar friction-stir-welded joints between AA5058 aluminum alloy and PMMA polymer. Welding in the World, 62, pp. 117-130, 2018

[13] Y. Farazila, Y. Miyashita, W. Hua, Y. Mutoh, Y. Otsuka: Yag laser spot welding of pet and metallic materials. Journal of Laser Micro/Nanoengineering, 6, pp. 69-74, 2011

[14] Y. Farazila, M. Fadzil, M. Hamdi: A brief review: laser joining of polymermetal structures. ASEAN Engineering Journal, 2(2), pp. 5-12, 2012

[15] A. Fortunato, G. Cuccolini, A. Ascari, L. Orazi, G. Campana, G. Tani: Hybrid metal-plastic joining by means of laser. International Journal of Material Forming, 3, pp. 1131-1134, 2010

[16] J. Hirsch: Recent development in aluminium for automotive applications. Transactions of Nonferrous Metals Society of China, 24, pp. 1995-2002, 2014

[17] Y. Huang, X. Gao, Y. Song, N. Zhang, N. Ma: Visual inspection of pulsed Nd:YAG laser welding of PMMA and stainless steel 304. Conference paper submitted to the 2017 IEEE International Conference on Imaging Systems and Techniques (IST) https://doi.org/10.1109/ist.2017.8261528

[18] F. I. Hussein, E. Akman, B. Genc Oztoprak, M. Gunes, O. Gundogdu, E. Kacar, K. I. Hajim, A. Demir: Evaluation of PMMA joining to stainless steel 304 using pulsed Nd:YAG laser. Optics \& Laser Technology, 49, pp. $143-152,2013$

[19] F. I. Hussein, K. N. Salloomi, E. Akman, K. I. Hajim, A. Demir: Finite element thermal analysis for PMMA/st.st.304 laser direct joining. Optics \& Laser Technology, 87, pp. 64-71, 2017

[20] K.-W. Jung, Y. Kawahito, M. Takahashi, S. Katayama: Laser direct joining of carbon fiber reinforced plastic to zinc-coated steel. Materials \& Design, 47, pp. 179-188, 2013 
[21] K.-W. Jung, Y. Kawahito, M. Takahashi, S. Katayama: Laser direct joining of carbon fiber reinforced plastic to aluminum alloy. Journal of Laser Applications, 25, 032003, 2013

[22] P. Kah, R. Suoranta, J. Martikainen, C. Magnus: Techniques for joining dissimilar materials: metals and polymers. Reviews on Advanced Materials Science, 36, pp. 152-164, 2014

[23] D. Lehmhus, A. von Hehl, J. Hausmann, K. Kayvantash, R. Alderliesten, J. Hohe: New materials and processes for transport applications: going hybrid and beyond. Advanced Engineering Materials, 1900056, pp. 1-7, 2019

[24] F. C. Liu, P. Dong: Promising high-speed welding techniques for joining polymers and metals and underlying joining mechanisms. In: Friction stir welding and Processing X, The Minerals, Metals \& Materials Series (Eds.: Y. Hovanski, et al.) https://doi.org/10.1007/978-3-030-05752-7_2

[25] T. Markovits, M. Berczeli: Examination of metal side heating of LAMP joint by $\mathrm{CO} 2$ laser beam. Materials Engineering - Materiálové inžinierstvo, 24, pp. 82-87, 2017

[26] PMJoin: Development of a direct laser joining of hybrid plastic-metal components for industrial applications, 2016

[27] J. Rauschenberger, A. Cenigaonaindia, J. Keseberg, D. Vogler, U. Gubler, F. Liébana: Laser hybrid joining of plastic and metal components for lightweight components. From Conference Volume 9356 High-Power Laser Materials Processing: Lasers, Beam Delivery, Diagnostics, and Applications IV Friedhelm Dorsch. San Francisco, California, United States, February 07, 2015, https://doi.org/10.1117/12.2080226

[28] E. Rodríguez-Vidal, C. Sanz, J. Lambarri, J. Renard, V. Gantchenko: Laser joining of different polymer-metal configurations: Analysis of mechanical performance and failure mechanisms. Physics Procedia, 83, pp. 1110-1117, 2016

[29] Vinny R. Sastri: Plastics in Medical Devices: Properties, Requirements and Applications. William Andrew Inc., Waltham, MA, 2014

[30] K. F. Tamrin, Y. Nukman, S. S. Zakariyah: Laser lap joining of dissimilar materials: a review of factors affecting joint strength. Materials and Manufacturing Processes, 28(8), pp. 857-871, 2013

[31] X. Tan, J. Zhang, J. Shan, S. Yang, J. Ren: Characteristics and formation mechanism of porosities in cfrp during laser joining of cfrp and steel. Composites Part B: Engineering, 70, pp. 35-43, 2015

[32] A. Taub, E. De Moor, A. Luo, D. K. Matlock, J. G. Speer, U. Vaidya: Materials for automotive lightweighting. Annual Review of Materials Research, 49, pp. 327-359, 2019 
[33] T. Temesi, Z. Kiss, T. Csiszér: Korszerü technológiák fém és polimer anyagok közötti kötések kialakítására. Acta Periodica, 15. kötet; Felkészülés az új évtizedre: a technológia és a gazdaság új kihívásai, pp. 115-125, 2018

[34] T. Temesi, L. Molnár, T. Csiszér: Az acél-polimer kötés az alagút végén eredmények a fém-polimer hibrid szerkezetek lézersugaras kötéstechnológiájának kutatásában. The steel-polymer joint at the end of the tunnel - results of research in the joining of metal-polymer hybrid structures with a laser beam. Acta Periodica, XIX. kötet: Tudomány és modern világ és fundamentumok, pp. 86-98, 2020

[35] J. Zhou, X. Wan, Y. Li: Advanced aluminium products and manufacturing technologies applied on vehicles presented at the eurocarbody conference. Materials Today: Proceedings, 2, pp. 5015-5022, 2015 